\title{
TÜRKIYE'DE FIYAT
}

\section{DÜZEYINIIN MALİ TEORİSI VE}

RICARDOCU MALIYE

\author{
Hacettepe Üniversitesi \\ iktisadi ve Idari Bilimler \\ Fakültesi Dergisi, \\ Cilt 36, Sayı 2, 2018, \\ s. $149-170$
}

\section{POLİTİKASI (1975-2014)}

\author{
Mehmet SONGUR \\ Arş.Gör.Dr., Munzur Üniversitesi \\ İktisadi ve İdari Bilimler Fakültesi \\ İktisat Bölümü \\ mehmetsongur@munzur.edu.tr
}

Filiz ELMAS SARAÇ

Prof.Dr., Gazi Üniversitesi

İktisadi ve İdari Bilimler Fakültesi

İktisat Bölümü

ozfiliz@gazi.edu.tr

Bu çalıșma, 5-6 Kasım 2015 tarihlerinde gerçekleştirilmiş olan EY International Congress on Economics II'da M. Songur tarafindan sunulan "Ricardocu Maliye Politikası ve Fiyat Düzeyinin Mali Teorisi: Türkiye Örneği (1975-2014)" başılılı bildirinin gözden geçirilmiş ve genişletilmiş versiyonudur.

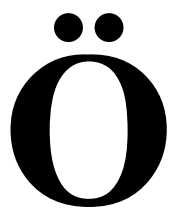

z: Geleneksel makro iktisat teorisinde, fiyat düzeyinin belirlenmesi hususunda maliye politikalarının önemli olup olmadığı konusunda tartışmalar yer almaktadır. Bu bağlamda Ricardocu Maliye Politikası (RFPs)'nı savunan iktisatçılara göre, fiyat düzeyinin belirlenmesinde maliye politikası önemli değildir. RFPs'nda kamu borcu faiz dışı bütçe fazlasının en önemli belirleyicisidir. Diğer taraftan bazı iktisatçılar fiyat düzeyinin belirlenmesinde maliye politikalarının önemli olduğunu iddia etmişlerdir. Bu yaklaşıma Fiyat Düzeyinin Mali Teorisi (FTPL) denilmektedir. FTPL'ye ya da Ricardocu olmayan maliye politikasına göre, maliye politikasının geçerli disiplinden yoksun olduğu yıllarda, merkez bankası tarafından fiyat istikrarını sağlamak için etkin politikalar uygulanamayacağı ileri sürülmüştür. Avrupa Birliği'ne aday ülke konumunda bulunan Türkiye'nin fiyat düzeyinin belirlenmesinde maliye politikasının etkisinin araştırılması önemlidir. Çalışmanın temel amacı, Türkiye'de RFPs'nin ya da FTPL'nin geçerliliğini analiz etmektir. Veri seti 1975-2014 dönemini kapsamaktadır. Kurulan model zaman serisi tekniklerinden ARDL Sinır Testi Yaklaşımı ile test edilmiştir. Yapılan analize göre söz konusu dönemde RFPs geçerlidir. Bu bağlamda, Türkiye'de Maastricht Kriterleri'ni sağlayacak şekilde mali disiplinin sürdürülmesi önemlidir.

Anahtar Sözcükler: Ricardocu maliye politikast, fiyat düzeyinin mali teorisi, zaman serisi analizi. 
FISCAL THEORY OF THE

\section{PRICE LEVEL AND RICARDIAN}

\section{FISCAL POLICY IN}

\section{TURKEY (1975-2014)}

\author{
Hacettepe University \\ Journal of Economics \\ and Administrative \\ Sciences \\ Vol. 36, Issue 2, 2018 \\ pp. $149-170$
}

\author{
Mehmet SONGUR \\ Res.Assist., Munzur University \\ Faculty of Economics and Administrative \\ Sciences \\ Department of Economics \\ mehmetsongur@munzur.edu.tr \\ Filiz ELMAS SARAÇ \\ Prof.Dr., Gazi University \\ Faculty of Economics and Administrative \\ Sciences \\ Department of Economics \\ ozfiliz@gazi.edu.tr
}

This study is a revised and extended version of the paper titled "Ricardian Fiscal Policy and Fiscal Theory of the Price Level: The Case of Turkey (1975-2014)" which was presented by $M$. Songur during EY International Congress on Economics II on $5^{\text {th }}-6^{\text {th }}$ November, 2015.
A

bstract: In the traditional macroeconomic theory, there are many debates as to whether fiscal policies are important in determining the price level. In this context, according to economists who advocate the Ricardian Fiscal Policy (RFPs), fiscal policy does not matter in determining the price level. For RFPs, public debt is the most important determinant of the primary surplus. On the other hand, some economists have argued that fiscal policies are important in determining the price level. This approach is called the Fiscal Theory of the Price Level (FTPL). According to the FTPL or non-Ricardian fiscal policy, it has been argued that the central bank will not be able to implement effective policies to maintain price stability over the years when fiscal policy is lacking the current discipline. It is important to investigate the effect of fiscal policy in determining the price level of Turkey, which is a candidate country for the European Union. The main purpose of this study is to analyze the validity of RFPs or FTPL in Turkey. Data covers the 1975-2014 period. The established model was tested by ARDL bounds testing approach from time series techniques. RFPs is valid in that period according to the performed analysis. In this context, it is important to maintain fiscal discipline in order to ensure Maastricht criteria in Turkey.

Keywords: Ricardian fiscal policy, fiscal theory of the price level, time series analysis. 


\section{GíRiş}

Fiyat düzeyi belirlenirken maliye politikasının etkisinin olmadığı görüşü oldukça eskiye -klasik miktar teorisine kadar- dayanmakla birlikte, söz konusu görüşün geçerliliği üzerine tartı̧malar günümüzde hala devam etmektedir. Maliye politikasının fiyat düzeyinin belirlenmesinde herhangi bir etkisinin olmadı̆̆ını savunan görüş̧ "Ricardocu Denklik Teoremi" üzerine temellenmekte ve uygulanan bu tür maliye politikalarnna Ricardocu Maliye Politikası (RFPs) adı verilmektedir. RFPs'nin günümüzde tartışılmasının en önemli nedeni 1990’lı yıllarda Fiyat Düzeyinin Mali Teorisi (FTPL) olarak anılan görüşün ortaya atılmasıdır. Ricardocu olmayan maliye politikalarının temel çıkarsaması fiyat düzeyinin belirlenmesinde maliye politikasının önemli olduğudur.

Ricardocu maliye politikası uygulamaları -örneğin kamu borcu- fiyat düzeyini etkilememekte iken, Ricardocu olmayan politikalara göre para ve maliye politikası birbirine bağlı bir şekilde yürütülmektedir. Ricardocu maliye politikasında faiz dışı bütçe fazlası kamu borcuna bağlı olarak belirlenmekte ve maliye politikasında birincil hedef olarak faiz dışı bütçe fazlası belirlenmektedir. Ricardocu olmayan politikalarda ise faiz dışı bütçe fazlasının belirlenmesinde kamu borcu önem arz etmemektedir.

Bu bağlamda Avrupa Birliği’ne aday ülke konumunda bulunan Türkiye'nin fiyat düzeyinin belirlenmesinde maliye politikasının etkisinin araştııılması büyük önem kazanmaktadır. Bu çerçevede, Elmas ve Songur (2016)'un Avrupa Birliği Ekonomik ve Parasal Birlik üyesi ülkelerde Ricardocu ya da Ricardocu olmayan maliye politikalarının geçerliliğini analiz ettikleri çalışma önem arz etmektedir. Söz konusu çalışmada Elmas ve Songur (2016) Avrupa Birliği Ekonomik ve Parasal Birlik üyesi 11 ülke için Ricardocu maliye politikasının geçerli olduğu sonucuna ulaşmışlardır. Bu doğrultuda çalışmanın amacı, Türkiye'de -2001 krizi ve sonrasında uygulanan politikaları da dikkate alacak şekilde- fiyat düzeyini belirlenirken, maliye politikasının etkisini araştırmak bağlamında Ricardocu ya da Ricardocu olmayan maliye politikalarının geçerliliğini analiz etmektir.

Çalışmanın birinci bölümünde, RFPs ve FTPL'ye ilişkin teorik çerçeve sunulacaktır. İkinci bölümde, Türkiye'de fiyat düzeyi ve maliye politikası ilişkisi incelenecektir. Üçüncü bölümde, RFPs ve FTPL bağlamında Türkiye için yapılmış ampirik çalışmalara yer verilecektir. Dördüncü bölümde, çalışmada kullanılacak model ve veri seti ile ilgili bilgi verilecektir. Beşinci bölümde, ekonometrik analize ait yöntem anlatıldıktan sonra çalışmada gerçekleştirilen analize ilişkin bulgulara değinilecektir. Sonuç bölümünde ise, çalışmadan elde edilen sonuçlar irdelenecektir. 


\section{TEORISI}

1. RİCARDOCU MALIYY POLITIKASI VE FIYAT DÜZEYININ MALI

Geleneksel makro iktisat teorilerine göre genel fiyat düzeyinin belirlenmesi tamamen parasal bir olgudur. $\mathrm{Bu}$ çerçevede, genel fiyat düzeyinin istikrarının sağlanması için bağımsız bir merkez bankasına ihtiyaç vardır. Bağımsız bir merkez bankasının uygulayacağı para politikası uygulanan maliye politikasından bağımsız bir biçimde fiyat istikrarını sağlayacaktır. Uygulanan maliye politikalarının genişletici ya da daraltıcı olduğuna bakılmaksızın ekonomide bir servet etkisi yaratmayacak ve fiyat istikrarının bozulmasına neden olmayacaktır. İktisat yazınında bu görüş "Ricardocu Denklik Teoremi" olarak anılmaktadır.

Para ve maliye politikaları ekonomik istikrarın sağlanmasında ve devam ettirilmesinde kullanılan en önemli iki politika aracıdır. İktisat yazınına baktığımızda, belirlenen iktisadi hedefe göre para ve maliye politikalarını birbiri ile uyumlu ya da birbirinden bağımsız şekilde uygulanabileceği konusundaki tartı̧malar hala güncelliğini korumaktadır. Söz konusu tartışmaların yoğunlaştığı en önemli başıklardan birisi de fiyat istikrarının sağlanması hedefi bağlamında uygulanacak para ve maliye politikasının birbiri ile uyumlu mu yoksa birbirinden bağımsız $\mathrm{m}$ hareket edeceğidir. Örneğin, maliye politikasının kontrol altına alınamadığı yani genişletici maliye politikasının uygulandığı dönemlerde, gerçekleşen bütçe açıklarının finansmanı eğer para politikası araçları kullanılmak suretiyle gerçekleştirilirse, para arzının artması yoluyla fiyat istikrarı bozulacaktır. Bu nedenle, para ve maliye politikasının uygulanma aşamasında birbiri ile ilişkisi önem kazanmaktadır.

Barro (1974) kamu harcamalarının servet etkisine dikkat çekerek Ricardocu Denklik Teoremi ile ilgili ilk tartışmayı başlatmıştır. Barro (1974)'ya göre kamu harcamaları vergi ile değil de borçlanma ile finanse edilirse bireyler servetlerinin arttığını algılayacak ve tüketimi arttıracaklardır. Tüketimin artması toplam talebi arttırırken, faizlerin artması bağlamında ortaya çıkan dışlama etkisi ile yatırımları ve sermaye birikimini azaltacaktır. Fakat Barro (1974)'ya göre rasyonel davranan bir birey borçlanma ile finanse edilen kamu harcamalarının ilerdeki kamu borcunu arttıracağını ve bu borçlarında vergilerle finanse edileceğini bilmektedir. Bu nedenle söz konusu birey, rasyonel beklentiler ve yaşam boyu gelir hipotezi bağlamında, iktisadi kararlarını ve tüketim kalıbını değiştirmeyecektir. Bu nedenle kamu borcu finansmanı ister vergi ile sağlansın isterse de borçlanma ile sağlansın iki finansman biçimi de rasyonel davranan bireyin ekonomik kararları üzerinde etkili olmayacaktır (Arıcan, 2005: 84-85). Buchanan (1976) ise çalışmasında Barro (1974)'nun ileri sürdüğü görüşlerin Ricardo tarafından daha önce ortaya atıldığını belirtmiş ve teoremin adı iktisat yazınında "Ricardocu Denklik Teoremi" olarak yer almıştır. Dolayısıyla uygulanan maliye 
politikası ve onun finansman biçimi ne olursa olsun tüketimi ve toplam talebi etkilemeyeceği için fiyat düzeyi üzerinde herhangi bir değişikliğe neden olmayacaktır.

Diğer taraftan FTPL savunucuları [Leeper (1991), Sims (1993), Woodford (1994, 1995, 2001) ve Cochrane (2001)] maliye politikasının kontrol altına alınmadığı dönemlerde merkez bankasının fiyat istikrarını sağlamak için etkin politikalar yürütemeyeceğini ileri sürmüşlerdir. Bu bağlamda FTPL savunucuları genel fiyat düzeyinin, zamanlararası bütçe kısıtı ${ }^{1}$ tarafından belirleneceğini ileri sürmektedirler.

İlgili iktisadi yazına baktığımızda, genel fiyat düzeyinin geleneksel makro iktisat teorilerine uygun olarak belirlendiği politikalar Ricardocu Maliye Politikası (RFPs) olarak tanımlanır. RFPs'na göre genel fiyat düzeyinin belirleyicisi bağımsız bir merkez bankasının uygulayacağı bağımsız para politikasıdır. Genel fiyat düzeyindeki değişimlerin maliye politikası uygulamalarından kaynaklandığı politikalar ise Ricardocu olmayan maliye politikaları olarak tanımlanır. Fiyat düzeyinin belirlenmesinde para politikası baskın ise Ricardocu maliye politikası geçerli iken, maliye politikası baskın ise Ricardocu olmayan maliye politikası geçerlidir (Saçkan, 2006: 1).

Leeper (1991) çalışmasında, para ve maliye politikaları arasındaki ilişkiye vurgu yapmıştır. Leeper (1991) kamu borçlarını dikkate alıp almadığına göre para ve maliye otoritelerini "aktif" ve "pasif" olarak tanımlamıştır. Aktif otorite, kamu borcu düzeyini dikkate almadan kontrol ettiği değişkenleri belirlemektedir. Pasif otorite ise, kamu borcu şoklarına karşılık vermektedir. Fakat pasif otoritenin davranışları hane halkının optimizasyon problemi ve aktif otoritenin hareketleri tarafından kısıtlanmıştır. Leeper (1991)'a göre, istikrarlı bir fiyat düzeyi için bir politika aktif ise diğeri mutlaka pasif olmalıdır. Her iki politika da aktif ya da pasif ise, enflasyonist ya da deflasyonist durumların ortaya çıkabileceğini belirtmiştir.

Sims (1993) çalışmasında, Ricardocu Denkliğin sağlanmasının her zaman geçerli olan bir durum olmadığını belirtmiştir. Fiyat düzeyinin sadece para politikasına bağlı olarak belirlenmeyeceğini, fiyat düzeyinin belirlenmesinde maliye politikasının da önemli bir rol oynadığını ifade etmiş̧ir.

Bağımsız bir merkez bankası Ricardocu maliye politikası geçerli olduğunda temel hedefi fiyat istikrarının sağlanması ve korunmasıdır. Bu bağlamda merkez bankası maliye politikasının ne olduğuna bakmaksızın sadece fiyat istikrarına odaklanmaktadır. Fakat maliye politikası baskın olduğunda, merkez bankası fiyat istikrarına odaklanmakta olmasına rağmen maliye politikası açıklarının finansmanının merkez bankası kaynaklarından karşılanması nedeniyle fiyat düzeyinde bozulmalar ortaya çıkmakta ve arzu edilen fiyat hedefine ulaşılamamaktadır. 
SONGUR, ELMAS SARAÇ | Fiscal Theory of the Price Level and Ricardian Fiscal Policy...

Woodford (1995) fiyat düzeyinin belirlenmesinde maliye politikasının öneminden bahsetmiş ve zamanlararası bütçe kısıtının fiyat düzeyinin doğrudan bir belirleyicisi olduğunu ifade etmiştir. Woodford (1995) Ricardocu ve Ricardocu olmayan maliye politikası ayrımını yapan ilk kişidir.

Ricardocu maliye politikası geçerli olduğunda, mali otorite mevcut kamu borç düzeyinin veya borç yükünün değişmesine neden olan herhangi bir gelişme karşısında zamanlararası bütçe kısıtını sağlayacak şekilde faiz dışı fazlayı uyarlamaktadır. $\mathrm{Bu}$ durumda faiz dışı fazla kamu borç düzeyine duyarlı olduğundan fiyat düzeyi ne olursa olsun, her borç düzeyinde zamanlararası bütçe kısıtını otomatik olarak sağlanmaktadır. Dolayısıyla maliye politikası fiyat düzeyinin belirlenmesinde rol oynamazken, para arzı ve para talebi denklemleri fiyat düzeyini belirlemektedir. Diğer bir deyişle, klasik miktar teorisi yaklaşımı geçerlidir. Böylelikle para politikası fiyat istikrarına maliye politikası ise faiz dışı bütçe fazlası vermeye odaklanmaktadır. Ricardocu olmayan maliye politikasında ise, faiz dışı fazla zamanlararası bütçe kısıtını sağlayacak şekilde uyarlanmamaktadır. Diğer bir ifade ile kamu bütçe kısıtı maliye politikası için sağlanması gereken bir hedef olmaktan çıkmaktadır. Böyle bir durumda zamanlararası bütçe kısıtını sağlamak için fiyat düzeyi değişmelidir. Dolayısıyla fiyat düzeyi zamanlararası bütçe kısıtı tarafından belirlenmekte ve mali şoklar fiyat düzeyinde değişmeye yol açmaktadır (Güney, 2009: 31).

Woodford (1996)'a göre FTPL hem kapalı hem de açık bir ekonomide uygulanabilir. Eğer açık bir ekonomi çerçevesinde bir ülke parasal birlik içinde ise diğer ülkelerin maliye politikası rejimleri büyük önem arz etmektedir. Parasal birlik içinde yer alan tüm ülkeler RFPs uyguluyorlarsa mali şoklar parasal ve reel değerleri etkilemeyecektir. Woodford (1996)'a göre iki ülkeli modelde iki ülke de Ricardocu Rejime sahip ise, mali şokların enflasyon, faiz ve çıktıyı etkilemesi söz konuşu değildir. Ancak ülkelerden birisi Ricardocu olmayan politika izliyor ise, iki ülkede de enflasyon, faiz ve çıktıda çarpıklıklar yaratacaktır.

Eğer Avrupa Birliği Ekonomik ve Parasal Birliği’nde olduğu gibi çok sayıda para ve maliye otoritesinin bulunduğu bir parasal birlik olur ise, para ve maliye politikalarının koordinasyonu önemlidir. Eğer birlik içindeki her ülke faiz dışı fazla ve sabit nominal faiz haddi uygulamasına giderse, tek bir genel fiyat düzeyi oluşabilir, fakat bazı ülkeler sürekli açık vermeyi sürdürebilir. Bu noktada her ülke faiz dışı fazla verme taahhüdünde bulunmalı ve bunu sağlamalıdır. Parasal birlik üyesi ülkelerde para ve maliye politikalarının koordinasyonu büyük önem arz etmektedir (Sims, 1997: 3-6). 


\section{1975-2014 DÖNEMINDE TÜRKIYYE'DE FIYAT DÜZEYİ VE MALIYYE POLITIKASI}

Türkiye 1980'lerin başına kadar kalkınma planları bağlamında ekonomi politikalarını yürütmüştür. Söz konusu dönemde, para politikası maliye politikasına bağlı kalarak uygulanmıştır. Maliye politikası sonucunda ortaya çıkan açıklar uygulanan para politikaları ile kapatılmaya çalışılmıştır. Bu nedenle para politikasının birincil hedefi maliye politikası açıklarını kapatmak olmuştur. Bu bağlamda kamu finansman açıkları TCMB'den alınan avanslar ile karşılanmışıı. Özellikle 1977-79 yılları arasında KİT'lerin finansman ihtiyaçlarını karşılamak için giderek artan biçimde TCMB kaynaklarına başvurulduğundan emisyon hacmi önemli bir şekilde $\operatorname{artmıştır~}^{2}$. Para arzının genişlemesi söz konusu dönemde fiyat artışlarını da beraberinde getirmiştir. 1977'den sonra fiyat istikrarı ciddi bir biçimde bozulmuş, 1980 yılına gelindiğinde enflasyon oranı \%100'ü aşmıştır. 1975-1979 dönemi boyunca kamu borçlanma gereğinin GSYH'ye oranı yıllık ortalama \%4.37 olarak gerçekleşmiştir.

24 Ocak 1980 kararları ile birlikte istikrar ve serbestleşme programlarına geçiş başlamıştır. Programın kısa vadeli amaçlarından birisi enflasyonu kontrol altına almaktır. Bu nedenle iç talebi kontrol etmek amacıyla KİT mallarına yüksek oranlı zamlar yapılmış ve para arzı kontrol altına alınmıştır. 1980 'de \%100'ü aşan enflasyon oranı 1981'de \%36.8'e ve 1982 'de \%27.1'e kadar düşürüldü. Fakat 1980 'li yılların ikinci yarısında daha yüksek büyüme oranlarını yakalamak için uygulanan genişletici para ve maliye politikası sonucunda para arzı kontrol altına alınamamış ve enflasyon oranı ile birlikte Şekil 1'den de görüleceği üzere kamu kesimi borçlanma gereği artmaya başlamıştır. Böylece 1982'de \%2.7 olarak gerçekleşen kamu borçlanma gereği, 1987 yılında tekrar \%4.5'e kadar yükselmiştir. Bu dönemde kamu kesimi borçlanma gereğinin artmasının en önemli nedeni para arzının bütçe politikalarına bağımlı olmasıdır. Başka bir ifade ile kamu harcamalarının kontrol altına alınamaması yani bir disipline sahip olmaması daha fazla iç ve dış borçlanma ihtiyacı doğurmuş buna bağlı olarak da para arzı kontrol altına alınamamıştır. 1990'lı yıllarla birlikte borç yükü hızlı bir şekilde artmıştır. 1990'lı yılların ilk yarısında kamu harcamalarının sürekli olarak artmasına karşılık, kamu gelirlerinin KITT zararları sosyal güvenlik kuruluşlarının dengelerindeki bozulma nedeniyle yeterince arttırılamaması kamu kesimi açıklarını büyütmüştür. Öyle ki 1991-1993 döneminde kamu kesimi borçlanma gereğini GSYH'ye oranı y1llık ortalama \%7.7 olarak gerçekleşmiştir. Bununla birlikte 5 Nisan 1994 kararları çerçevesinde alınan gelir arttırıcı ve gider azaltıcı önlemler sonucunda kamu kesimi borçlanma gereği önemli ölçüde daraltılarak 1994'de \%4.6'ya, 1995'de de \%3.7’ye kadar düşürülmüştür. 5 Nisan 1994 kararlarında kamu kesimi açıklarının kapatılmasında TCMB kaynaklarının kullanılmayacağı ifade edilmesine rağmen 1994 yılının ikinci yarısında TCMB kaynaklarına başvurulmuştur. Bu nedenle, 1994 yılında enflasyon \%150'lere kadar ulaşmış ve 1995 yılında da para politikasının amacı bu 
enflasyon oranını düşürmek üzerine kurgulanmıştır. Ancak para arzının kontrol altına alınamaması 5 Nisan 1994 kararlarının başarısız olmasının en önemli nedenlerinden birisi olmuştur.

1995-1999 döneminde de para arzı kontrol altına alınamamıştır. Bunun en önemli nedeni kamu kesimi gelir-gider dengesinin sağlanamamış olması ve kamu kesimi açıklarının TCMB kaynaklarının kullanılması ile giderilmesidir. Bu dönemde kamu kesimi borçlanma gereği hızla artmış 1999 yılında \%11.6'ya ulaşmıştır. Borçlanma gereği, \%100'lere varan yüksek faizlerle karşılanmış ve ekonomi borç-faiz kısır döngüsüne sürüklenmiştir. Bu dönem her ne kadar para politikasının bağımsızlığ yönünde adımlar atılmış olsa da önceki dönemlere benzer şekilde kamu disiplininin sağlanamaması ve kamu açıklarının TCMB kaynaklarından giderilmesi nedeniyle bağımsız para politikasının uygulanamadığı bir süreçtir.

\section{Şekil 1. Kamu Kesimi Borçlanma Gereği ve Faiz Dışı Fazla (1975-2014)}

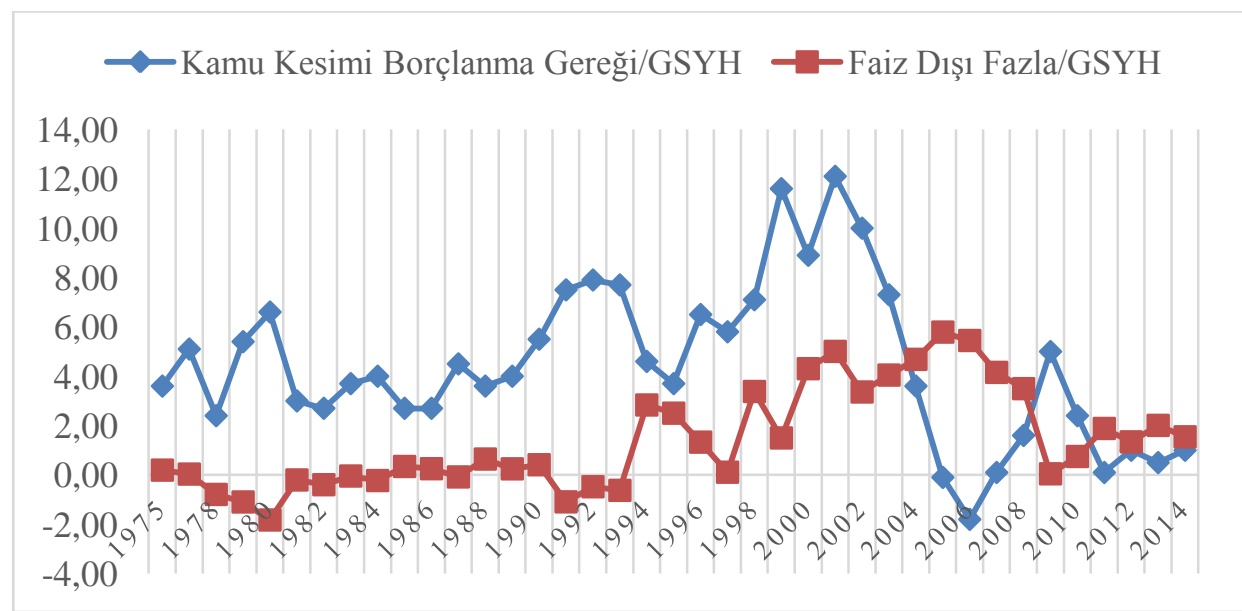

Kaynak: Bütçe ve Mali Kontrol Genel Müdürlüğü, Kalkınma Bakanlığı ve TCMB EVDS.

1980 sonrasında başlayan ve 1990'dan sonra yoğunlaşan yüksek enflasyon ve mali disiplinsizlik kaynaklı istikrarsızlıklar birçok iktisadi krize neden olmuştur. Ancak ne 5 Nisan 1994 kararları ne de 1 Ocak 2000 Enflasyonu Düşürme Programı gibi istikrar programları enflasyonu düşürmede ve mali istikrarı sağlamada başarılı olamamıştır. Özellikle kamu borçlanma gereği 1999'da \%8.9'a gerilese de 1 Ocak 2000 Enflasyonu Düşürme Programı'nın başarısızlığı nedeniyle kamu kesimi borçlanma gereği Şekil 1'de görüldüğü üzere, 2000 yılında tekrar \%12.1 gibi bir rekor düzeye ulaşmıştır. Bu durumun en önemli nedeni ise borçlanmanın yüksek faiz ile sürdürülmek zorunda kalınmasıdır. 
2001 yılında yaşanan ekonomik kriz sonrasında Güçlü Ekonomiye Geçiş Programı (GEGP) uygulamaya konulmuştur. Söz konusu program ile mali disiplin için maliye politikasının faiz dışı bütçe fazlası hedefine yönelik olarak yürütülmesi esası getirilirken, TCMB Kanunu'nda yapılan değişiklikler ile para politikasının birincil amacının fiyat istikrarını sağlamak ve sürdürmek olduğu hükme bağlanmış ve TCMB'na bu amaca yönelik olarak politika araçlarını seçme ve uygulama bağımsızlığı tanınmıştır. 2001 sonrası dönemde ekonomik programa bağlılık TCMB'nın enflasyonu düşürme yönünde gösterdiği kararlılık ile enflasyon oranı uzun yıllar sonra tek haneli rakamlara düşmüştür. $\mathrm{Bu}$ durum 2001 sonrası dönemde iktisadi politika rejiminin para politikası baskın özellikler gösterdiği izlenimini oluşturmaktadır (Saçkan, 2006: 22-23).

GEGP'de, kamu kesiminde, gelir-gider dengesinin sağlanması, borçlanma gereğinin azaltılması ile bütçe disiplinine özen gösterilmesi ve azami tasarruf ile hareket edilmesi, maliye politikasının temel yaklaşımı olarak vurgulanmıştır. Temel maliye politikası hedefi yüksek oranlarda faiz dışı fazla verilmesi olarak belirlemiş̧ir. Bu doğrultuda 2001 'de \%12.1'den kamu kesimi borçlanma gereğinin GSYH'ya oranı 2006 y1lında \%-1.8'e kadar gerilemiştir. Bu durum 2001'den sonra maliye politikasında ciddi bir rejim değişikliğinin en önemli göstergesi olarak karşımıza çıkmaktadır.

2001 öncesinde maliye politikasına bağlı olarak hareket eden para politikası uygulamasının, 2001 sonrasında para ve maliye politikalarının birbirinden bağımsız bir rejime dönüştükleri görülmektedir. Bu durum Ricardocu Maliye Politikası'na yönelme olarak değerlendirilebilir. Öyle ki para politikası sadece enflasyon hedeflemesine dayalı olarak fiyat istikrarını sağlamaya ve sürdürmeye odaklanmıştır. Maliye politikası ise mali disipline yönelik uygulamalar çerçevesinde gelir-gider dengesinin sağlanmasını ve kamu kesimi borçlanma gereğinin düşürülmesi ile birlikte faiz dışı fazla vermeye odaklanmıştır.

2008'de dünya ölçeğinde yaşanan ekonomik kriz bağlamında kamu kesimi borçlanma gereği ve faiz dışı fazlada kısmi bozulmalar yaşansa da krizin etkisinin geçmesi ile birlikte Şekil 1'den görüleceği üzere kamu kesimi borçlanma gereği azalırken, bütçede faiz dışı fazla verilmeye devam edilmiştir. 2001 sonrasında Avrupa Birliği yolunda önemli adımlar atılması da Güçlü Ekonomiye Geçiş Programı'nın uygulanmasındaki başarı düzeyinde önemli olmuştur. Maastricht Kriterleri'ne uygun bir şekilde bütçe açıklarını ve kamu borcunu dikkate alan politikalar uygulanması önem kazanmıştır.

$\mathrm{Bu}$ çalışmanın temel kaynăğ olan Elmas ve Songur (2016) çalışmalarında Avrupa Birliği Ekonomik ve Parasal Birlik üyesi ülkelerde Ricardocu Maliye Politikası'nın geçerli olduğu sonucuna ulaşılmış olmasıdır. Bu bağlamda, 2001 sonrasında Avrupa Birliği adaylığına daha fazla yaklaşan Türkiye'nin de Ricardocu 
SONGUR, ELMAS SARAÇ | Fiscal Theory of the Price Level and Ricardian Fiscal Policy...

Maliye Politikası'na yönelmesi beklenen bir durum haline gelmiştir. Tüm bu değerlendirmeler çerçevesinde, 2001 yılında gerçekleşen iktisadi politika rejimindeki değişiklik çalışmanın ampirik bölümünde dikkate alınmıştır.

\section{AMPİRIK LITERATÜR}

Çalışmanın bu bölümünde Fiyat Düzeyinin Mali Teorisi çerçevesinde Ricardocu maliye politikası ve Ricardocu olmayan maliye politikası geçerliliğini Türkiye için sınayan ampirik çalışmalara yer verilecektir.

Metin (1995) çalışmasında, Türkiye'de yüksek enflasyon oranlarının söz konusu olduğu üç alt dönem için (1954-1959, 1977-1980 ve 1984-1995) bütçe açıklarının enflasyon oranı üzerindeki etkisini, Engle-Granger eşbütünleşme testi yardımıyla incelemiştir. Elde edilen bulgular, bütçe açıklarının ilgili alt dönemlerde enflasyon oranını pozitif etkilediğini göstermektedir. Yine Metin (1998)'in çalışmasında, Türkiye için enflasyon ve bütçe açıkları arasındaki ilişkiyi Johansen eşbütünleşme testi yardımıyla incelemiştir. Buna göre elde edilen bulgular, enflasyonun önemli ölçüde gelir artışları ve borcun monetizasyonu kadar bütçe açıklarını arttırdığını göstermektedir.

Fiyat düzeyinin mali teorisi, Ricardocu miktar teorisine alternatif olarak sürülen fiyat ve enflasyon ilişkisi üzerinde durmakta ve miktar teorisi temelli parasalcı yaklaşımın para politikası önermelerinden farklı olarak, uzun dönemde fiyat düzeyi ve enflasyonu belirleyen faktörün para miktarı değil, mali açıklar ve bu açıkların neden olduğu kamu borç stoku olduğunu vurgulamakta ve enflasyonu kontrol etmek için para politikasının ve merkez bankasının bağımsızlığının yeterli olmadığını ifade etmektedir (Uygur, 2001: 11).

Creel ve Kamber (2004) çalışmalarında, Türkiye için 1975-2002 dönemine ait yıllık verilerden yararlanarak VAR yöntemini kullanmış ve FTPL'nin geçerliliğini incelemişlerdir. Çalışmada, Afonso (2002)'nun kullandığı değişkenleri kullanmışlar ve Türkiye'de Ricardocu olmayan maliye politikasının geçerli olduğu sonucuna ulaşmışlardır.

Bildirici ve Ersin (2005) çalışmalarında, Türkiye'de FTPL’nin geçerliliğini 1933-2004 dönemi için Engle-Granger Eşbütünleşme Yöntemi ve Vektör Hata Düzeltme Modeli yardımıyla araştırmışlardır. Ele alınan dönemde iç borç stokunun enflasyonist etkilere sahip olduğu hipotezi reddedilemese de, Türkiye'de mali baskınlığın özellikle 1980 sonrasında arttığına işaret edilmektedir. Dolayısıyla, ekonomik krizlerin fiyat istikrarını uzun vadede amaçlayan politikaların başarısını olumsuz etkilediğini belirtmişlerdir. 
Saçkan (2006) çalışmasında, Türkiye için 1988-2005 dönemine ait üç aylık verilerden yararlanarak VAR analizi yardımı ile FTPL'nin geçerliliğini incelemiştir. Çalışmasında ilgili literatürdeki diğer çalı̧̧malardan farklı olarak birinci fazla/GSYH ile toplam kamu yükümlülükleri/GSYH değişkenlerine ek olarak konsolide bütçe faiz ödemeleri/GSYH değişkeni de kullanılmıştır. Ayrıca çalışma da ele alınan dönem 2001 kriz öncesi ve sonrası olarak ayrı ayrı analiz edilmiştir. Elde edilen bulgulara göre 19882001 döneminde Ricardocu olmayan maliye politikası geçerli iken, 2001-2005 döneminde ise Ricardocu maliye politikasının geçerli olduğu sonucuna ulaşıılmıştır. 1988-2005 döneminde ise Ricardocu olmayan maliye politikasının geçerli olduğu belirtilmiştir.

Güney (2007) çalışmasında, Türkiye için FTPL'nin geçerliliğini 1989:1-2005:4 dönemine ait üç aylık veriler yardımı ile ARDL sınır testi yaklaşımını kullanarak araştırmıştır. Elde edilen bulgular Türkiye'de Ricardocu olmayan maliye politikasının geçerli olduğunu göstermektedir.

Özaktaş (2008) çalı̧şmasında Türkiye'de 1987:1-2004:4 döneminde FTPL'nin geçerliliğini Johansen Eşbütünleşme ve VAR analizi yardımıyla araştırmıştır. Elde edilen bulgular enflasyonist süreçte mali değişkenlerin rolünün varlığının yadsınamaz olduğunu göstermekte olup Ricardocu olmayan maliye politikasının geçerli olduğu sonucuna ulaşılmıştır.

Temiz (2008) çalışmasında FTPL kapsamında Türkiye'de geçerli iktisat politika rejiminin araştırılması için, 1987:1-2005:4 dönemine ait yıllık veriler yardımı ile Johansen Eşbütünleşme ve VAR analizini kullanmıştır. Çalışmadan elde edilen sonuçlar bağlamında 2001 yılı öncesi ve sonrası dönemde Türkiye'de geçerli iktisat politika rejimi hakkında kesin bir karara varılamayacağını belirtilmiştir.

Oktayer (2010) çalı̧̧masında, Türkiye için 1987-2009 dönemine ait verilerden yararlanarak bütçe açığı, parasal genişleme ve enflasyon ilişsisi bağlamında Johansen Eşbütünleşme testi yardımı ile FTPL'nin geçerliliğini araştırmıştır. Sonuçlar, Türkiye'de uzun dönemde Ricardocu olmayan maliye politikasının geçerli olduğunu göstermektedir.

Uysal ve Pehlivan (2013) çalışmalarında, Avrupa Parasal Birliği’nde ve Türkiye'nin de yer aldığı Avrupa Birliği aday ülkelerinde 1995-2011 dönemine ait yıllık verilerden yararlanarak panel OLS yöntemi ile FTPL'nin geçerliliğini incelemişlerdir. Elde edilen bulgular her iki ülke grubunda da Ricardocu maliye politikasının geçerli olduğunu göstermektedir. 
Ampirik literatürde yer alan çalışmalara baktığımızda genel eğilimin Türkiye'de FTPL'nin geçerli olduğu yönündedir. Çalışmalar içerisinde Saçkan (2006) 2001-2005 döneminde Ricardocu maliye politikasının geçerli olduğu sonucuna ulaşmıştır. Ayrıca Uysal ve Pehlivan (2013)'da Türkiye'nin yer aldığı Avrupa Birliği aday ülkeler grubunda Ricardocu maliye politikasının geçerli olduğu sonucuna ulaşmışlardır. Bu iki çalışmanın dışında Temiz (2008) Türkiye'de geçerli iktisat politika rejimi hakkında kesin bir karara varılamayacağını belirtmiştir.

\section{MODEL ve VERİ SETI}

$\mathrm{Bu}$ çalışmada Türkiye için Ricardocu ya da Ricardocu olmayan maliye politikalarının geçerliliği zaman serisi teknikleri kullanılarak araştırılmıştır. Bu bağlamda analiz aşağıda kurulan model çerçevesinde gerçekleştirilecektir.

$$
F D D_{t}=\beta_{0}+\beta_{1} K B 1_{t}+\delta D u m m y+\varepsilon_{t}
$$

Modelde FDD, faiz dişı bütçe fazlası/GSYH değişkenini; KB1, kamu kesimi borçlanma gereği/GSYH değişkeninin bir dönem gecikmesini; Dummy, 2001 yılı için konulmuş kukla değişkeni; $\varepsilon_{t}$ ise, hata terimini ifade etmektedir. Kamu kesimi borçlanma gereği/GSYH değişkeninin bir dönem gecikmesinin modele dâhil edilme nedeni, faiz dışı bütçe fazlasının bir dönem öncesinde gerçekleşen kamu kesimi borçlanma gereğinden etkilenip etkilenmediğini araştırmaktır. Modelde kamu kesimi borçlanma gereği/GSYH değişkeninin bir dönem gecikmesine ait $\beta_{1}$ katsayısı önem arz etmektedir. Afonso (2002)'ye göre (i) modelde $\beta_{1} \leq 0$ ise, faiz dışı bütçe fazlası, kamu borcundaki değişmelere tepki vermemektedir. $\mathrm{Bu}$ nedenle, zamanlararası kamu bütçe kısıtının sağlanması genel fiyat seviyesine bağlıdır. O halde Ricardocu olmayan maliye politikasının geçerli olabileceği ifade edilebilir. (ii) Eğer modelde $\beta_{1}>0$ ise, hükümet mevcut kamu borç stoku artışını dengelemek için faiz dışı bütçe fazlasını arttırmaya çalışmakta ve zamanlar arası kamu bütçe kısıtının sağlanmasına yardım etmektedir. Bu durumda ise, Ricardocu maliye politikasının geçerli olduğu ifade edilebilir (Afonso, 2002: 23).

Çalışmada modele dâhil edilen 2 değişkene ait veri seti Bütçe ve Mali Kontrol Genel Müdürlüğü, Kalkınma Bakanlığı ve TCMB EVDS'den derlenmiş olup 19752014 dönemine ait yıllık verilerden oluşmaktadır. ${ }^{3}$

\section{YÖNTEM VE BULGULAR}

\subsection{Birim Kök Analizi}

Zaman serileri ile yapılan analizlerde değişkenler arasındaki ilişkiye bakmadan önce ele alınan değişkenlerin birim kök özelliklerini araştırmak gerekmektedir. Bu 
nedenle bu çalışmada Genişletilmiş Dickey-Fuller (ADF) (1981), Phillips-Perron (PP) (1988) ve Perron (1989) birim kök testleri kullanılmıştır.

ADF ve PP testi serinin durağan olduğu alternatif hipotezine karş1 yokluk hipotezinde serinin durağan olmadığı test edilir. Her iki testte de test istatistikleri belirlenen kritik değerden küçük ise yokluk hipotezi reddedilebilir.

Türkiye'de 2001 yilında meydana gelen kriz ve devamında gerçekleşen iktisadi politika rejimindeki değişiklik bağlamında 2001 yılında kırılma olduğu düşünülmektedir. $\mathrm{Bu}$ nedenle 2001 yılı için modelde bir kukla değişken oluşturulmuştur. Çalışmada bu kırılmayı dikkate alacak biçimde bir birim kök testi uygulamak gerekmektedir. $\mathrm{Bu}$ nedenle 2001 y1lı için bir kukla değişken oluşturulmuştur. Çalışmada bu kırılmayı dikkate alacak biçimde bir birim kök testi uygulamak gerekmektedir. Bu nedenle Perron (1989) tarafindan geliştirilen yapısal kırılmayı dikkate alan birim kök testi de kullanılmışır. Söz konusu testin en önemli özelliği kırılmanın önsel olarak bilindiği ve analize dışsal bir faktör olarak dâhil edilebilmesidir. Her üç birim kök testine ait sonuçlar Tablo 1'de sunulmuştur.

$\mathrm{ADF}$ ve PP birim kök testlerinden elde edilen sonuçlara baktığımızda, serilerin düzeyde birim kök içerdikleri fakat farkı alındıklarında serilerin durağan hale geldikleri görülmektedir. Yapısal kırılmanın dikkate alındığı Perron (1989) birim kök testine baktı̆̆ımızda her iki model içinde FDD serisi birinci dereceden farkı alındığında durağan hale gelmekte dolayısı ile ADF ve PP birim kök testleri ile benzer sonuçlar göstermektedir ${ }^{4}$. Fakat KB1 serisinin Perron (1989) birim kök testinde ADF ve PP birim kök testlerinden farklı olarak düzeyde durağan olduğu görülmektedir. Bu nedenle KB1 serisinin birim kök özelliği bağlamında gerçekleştirilen birim kök testleri arasında bir tutarlılık gözlenememiş̧ir. Bu durum bir sonraki aşamada eş bütünleşme testi ve tahminci seçiminde özellikle dikkate alınacaktır. 
SONGUR, ELMAS SARAÇ | Fiscal Theory of the Price Level and Ricardian Fiscal Policy...

Tablo 1. Birim Kök Analizi

\begin{tabular}{|c|c|c|c|c|}
\hline \multicolumn{5}{|c|}{ Genişletilmiș Dickey-Fuller (ADF) Birim Kök Testi } \\
\hline Değişkenler & $\begin{array}{l}\text { ADF-Test } \\
\text { İstatistiği }\end{array}$ & $\begin{array}{c}\text { MacKinnon Kritik } \\
\text { Değeri }(\% 5)\end{array}$ & Gecikme Uzunluğu (k) & \\
\hline $\mathrm{FDD}^{\mathrm{b}}$ & -2.693 & -3.530 & 1 & \\
\hline $\mathrm{KB} 1^{\mathrm{a}}$ & -2.103 & -2.939 & 1 & \\
\hline$\Delta \mathrm{FDD}^{\mathrm{c}}$ & $-7.917 * *$ & -1.950 & 1 & \\
\hline$\Delta \mathrm{KB} 1^{\mathrm{c}}$ & $-6.113 * *$ & -1.950 & 1 & \\
\hline \multicolumn{5}{|c|}{$\begin{array}{c}\text { Phillips-Perron (PP) Birim Kök Testi } \\
\end{array}$} \\
\hline Değişkenler & $\begin{array}{l}\text { PP Test } \\
\text { İstatistiği }\end{array}$ & $\begin{array}{c}\text { MacKinnon Kritik } \\
\text { Değeri }(\% 5)\end{array}$ & Bandwidth & \\
\hline $\mathrm{FDD}^{\mathrm{b}}$ & -2.622 & -3.530 & 1 & \\
\hline $\mathrm{KB} 1^{\mathrm{a}}$ & -2.240 & -2.939 & 2 & \\
\hline$\Delta \mathrm{FDD}^{\mathrm{c}}$ & $-8.420 * *$ & -1.950 & 6 & \\
\hline$\Delta \mathrm{KB} 1^{\mathrm{c}}$ & $-6.113 * *$ & -1.950 & 1 & \\
\hline \multicolumn{5}{|c|}{$\begin{array}{l}\text { Perron (1989) Birim Kök Testi } \\
\end{array}$} \\
\hline Değişkenler & Test İstatistiği & Kritik Değer (\%5) & Gecikme Uzunluğu (k) & Modeller \\
\hline FDD & -2.236 & -3.573 & 1 & Model A \\
\hline FDD & -3.913 & -4.195 & 1 & Model C \\
\hline KB1 & $-3.818 * *$ & -3.573 & 1 & Model A \\
\hline KB1 & $-3.890 * *$ & -3.573 & 1 & Model C \\
\hline$\Delta \mathrm{FDD}$ & $-7.872 * *$ & -3.593 & 1 & Model A \\
\hline$\Delta \mathrm{FDD}$ & $-7.927 * *$ & -3.593 & 1 & Model C \\
\hline$\Delta \mathrm{KB} 1$ & $-4.930 * *$ & -3.593 & 4 & Model A \\
\hline$\Delta \mathrm{KB} 1$ & $-5.468 * *$ & -4.200 & 4 & Model C \\
\hline
\end{tabular}

Not: $\Delta$ birinci derece fark işlemcisini ifade etmektedir. Üç birim kök testinde de Akaike Bilgi Kriterine göre sonuçlar alınmıştır. ADF ve Perron (1989) Birim Kök Testleri için maksimum gecikme uzunlukları 4 olarak alınmıştır. a, sadece sabitin olduğu model uygundur; $b$, sabit ve trendin olduğu model uygundur; c, sabit ve trendin olmadığı model uygundur. PP Birim Kök Testi'nde Barlett Kernel metodu kullanılmış olup, Bandwith Genişliği Newey-West yöntemi ile belirlenmiş̧tir. Perron (1989) Birim Kök Testinde kırılma tarihi dışsal olduğu için 2001 olarak alınmıştır. Perron (1989) Birim Kök Testinde Model A, sadece sabitte meydana gelen yapısal değişimi içerirken, Model $\mathrm{C}$, trend ve sabitte meydana gelen yapısal değişimi içermektedir.

ADF ve PP birim kök testlerinden elde edilen sonuçlara baktığımızda, serilerin düzeyde birim kök içerdikleri fakat farkı alındıklarında serilerin durağan hale geldikleri görülmektedir. Yapısal kırılmanın dikkate alındığı Perron (1989) birim kök testine baktığımızda her iki model içinde FDD serisi birinci dereceden farkı alındığında durağan hale gelmekte dolayısı ile ADF ve PP birim kök testleri ile benzer sonuçlar göstermektedir ${ }^{4}$. Fakat KB1 serisinin Perron (1989) birim kök testinde ADF ve PP birim kök testlerinden farklı olarak düzeyde durağan olduğu görülmektedir. Bu nedenle KB1 serisinin birim kök özelliği bağlamında gerçekleştirilen birim kök testleri arasında bir 
tutarlılık gözlenememiştir. Bu durum bir sonraki aşamada eş bütünleşme testi ve tahminci seçiminde özellikle dikkate alınacaktır.

\subsection{Sınır Testi (ARDL) Yaklaşımı}

$\mathrm{Bu}$ çalışmada, değişkenler arasındaki uzun dönemli eşbütünleşme ilişkisinin varlığını araştırmak için, ARDL sınır testi yaklaşımı tercih edilmiştir. Pesaran $v d$. (2001) tarafindan geliştirilen bu yöntemin diğer eş bütünleşme testlerinden birkaç avantajı vardır. Öncelikle ARDL Sınır Testi yaklaşımında gözlem sayısı az olan veri setleri ile analiz yapmanın bir sakıncası olmamasıdır. Bir diğer avantajı standart eş bütünleşme analizlerinde karşılaşılan ön test problemlerinden kaçınmaya olanak vermesidir. $\mathrm{Bu}$ çalışmada ARDL Sınır Testi yaklaşımının tercih edilmesinin temel nedeni olan avantajı ise, bağımlı değişkenin bütünleşme derecesinden etkilenmemesine olanak vermesidir. ARDL Sınır Testi yaklaşımı serilerin birim kök varlığı konusunda net bir yargıya varılamadığı durumlarda kullanışlı olmaktadır. ARDL Sınır Testi yaklaşımı bağımsız değişkenlerin düzeyde ya da birinci dereceden farkı alındığında durağan olup olmadığına bakılmaksızın değişkenler arasında eş bütünleşme ilişkisi araştırmaya imkan sağlamaktadır. Ancak serilerin ikinci dereceden farkı alındığında durağan hale geliyorsa ARDL Sınır Testi yaklaşımı kullanılamaz.

ARDL yaklaşımında dinamik bir kısıtlı VAR modeli tahmin edilerek modele dahil olan değişkenlerin gecikmelerinin istatistiksel olarak anlamlı olup olmadığı test edilir. ARDL sınır testi yaklaşımı çerçevesinde 1 numaralı model, uzun dönemli ilişkiyi araştırmak için (2) numaralı denklemlerde ifade edilen ARDL kısıtsız hata terimi modeli (UECM) ile tahmin edilir.

$\Delta F D D_{t}=\alpha_{0}+\alpha_{1} F D D_{t-1}+\alpha_{2} K B 1_{t-1}+\sum_{i=1}^{P} \lambda_{1 i} \Delta F D D_{t-1}+\sum_{i=1}^{P} \lambda_{2 i} \Delta K B 1_{t-1}+\delta D u m m y+\varepsilon_{t}$

İlgili değişkenler arasında eş bütünleşme ilişkisinin varlığını test etmek için 2 numaralı denklem EKK yöntemi ile tahmin edildikten sonra, test istatistiği gecikmeli değişkenlerin katsayılarının sıfira eşit olduğu $\left(H_{0}: \alpha_{1}=\alpha_{2}=0\right)$ yokluk hipotezi ile alternatif hipotez $\left(H_{0}: \alpha_{1} \neq \alpha_{2} \neq 0\right)$ test edilir. Hipotez testi için F-istatistik değeri kullanılır. Optimal gecikme uzunluğu ile elde edilen F-istatistiği Pesaran $v d$. (2001) tarafindan sunulan, biri tüm serilerin durağan olduğu, diğeri de tüm serilerin birinci dereceden farkı alındığında durağan olduğu duruma ilişkin iki kritik değer kümesi ile karşılaştırılır ve F-istatistik değeri üst kritik değeri aşarsa değişkenler arasında eşbütünleşme olduğu belirtilmektedir. 
SONGUR, ELMAS SARAÇ | Fiscal Theory of the Price Level and Ricardian Fiscal Policy...

Tablo 2. (2) Numaralı Denklemin Sınır Testi Sonuçları

\begin{tabular}{cccc}
\hline Bağımlı Değişken & Gecikme Uzunluğu (k) & F-istatistiği & $\begin{array}{c}\text { Kritik Değerler } \\
\text { (Alt Değer-Üst Değer) }\end{array}$ \\
\hline $\mathrm{F}_{\mathrm{FDD}}(\mathrm{FDD} \mid \mathrm{KB} 1)$ & 1 & 6.495 & $4.94-5.73$ \\
\hline
\end{tabular}

Not: Kritik değerler $\% 5$ anlamlılık düzeyine göre verilmiştir. Maksimum gecikme uzunluğu 4 olarak alınmış gecikme uzunluğu Akaike Bilgi Kriteri’ne göre belirlenmiştir. Narayan (2004) çalışmasında küçük örneklemler için kritik değerlerin farklılaştı̆̆ını belirtmektedir. Bu bağlamda 39 gözlem ve iki değişken için \%5 anlamlılık düzeyinde alt ve üst kritik değerler sırasıyla 3.937 ve 4.483'dir. Narayan (2004) kritik değerlerine göre de değişkenler arasında eşbütünleşme olduğu ifade edilebilir.

Sınır testi analizinden elde edilen F-istatistiğini kritik değerler ile karşılaştırdığımızda, hesaplanan F-istatistiği \%5 anlamlılık düzeyinde üst kritik değerin üzerinde yer almaktadır. Dolayısı ile değişkenler arasında eş bütünleşme ilişkisi olmadığını ileri süren yokluk hipotezi reddedilmektedir. Diğer bir ifade ile analize konu olan dönemde faiz dışı bütçe fazlası ile kamu borcu arasında uzun dönemli bir ilişki olduğu görülmektedir.

Değişkenler arasında uzun dönemli ilişkinin varlığının tespit edilmesinden sonra, ikinci aşamada bağımsız değişkenler için ARDL uzun dönem modeli tahmin edilmelidir. Bu bağlamda (1) numaralı model için ARDL uzun dönem tahmini (3) numaralı model yardımıyla elde edilir.

$$
\Delta F D D_{t}=\alpha_{0}+\sum_{i=1}^{P} \alpha_{1} \Delta F D D_{t-1}+\sum_{i=0}^{r} \alpha_{2} \Delta K B 1_{t-i}+\delta D u m m y+\varepsilon_{t}
$$

(3) numaralı modelden EKK yöntemi ile tahmin edilen ve gecikme uzunlukları Akaike Bilgi Kriteri'ne göre belirlenen ARDL $(1,3)$ modeline ait uzun dönem katsayı tahminleri Tablo 3 'te sunulmuştur.

Tablo 3. ARDL (1,3) Modeli Uzun Dönem Katsayı Tahminleri

\begin{tabular}{lcccc}
\hline Değişken & Katsayı & Standart Hata & t-istatistiği & Prop. \\
\hline C & -2.229 & 1.018 & -2.189 & $0.036^{* *}$ \\
KB1 & 0.569 & 0.192 & 2.962 & $0.000^{* * *}$ \\
Dummy & 2.887 & 0.776 & 3.720 & $0.000^{* * *}$
\end{tabular}

Not: $*, * *, * * *$ sirasıyla $\% 10, \% 5$ ve $\% 1$ düzeyinde istatistiksel olarak anlamlılık düzeyini ifade etmektedir 
Uzun dönem katsayılardan elde edilen sonuçlara baktığımızda KB1 değişkenine ait uzun dönem katsayı tahmini pozitif $(0.569)$ ve istatistiksel olarak $\% 5$ düzeyinde anlamlı bulunmuştur. Modele dâhil edilen kukla değişken pozitif ve $\% 5$ düzeyinde istatistiksel olarak anlamlı bulunmuştur. Bu durum 2001 yllnnda iktisadi politika rejiminin değiştiğini ve faiz dışı bütçe dengesini pozitif yönde etkilediğini göstermektedir.

Son aşamada ise, uzun dönem tahminler ile ilgili olarak 4 numaralı denklemde sunulan hata düzeltme katsayısı $(\eta)$ ile kısa dönem dinamik parametreler tahmin edilir.

$\Delta F D D_{t}=\alpha_{0}+\sum_{i=1}^{p} \beta_{1} \Delta F D D_{t-i}+\sum_{i=0}^{r} \beta_{2} \Delta K B 1_{t-i}+\delta D u m m y+\eta e c m_{t-1}+\varepsilon_{t}$

$e c m_{t-1}$ değişkeni (3) numaralı denklemlerde yer alan hata terimleri serisinin bir dönem gecikmeli değerini ifade ederken uzun dönemde düzeltilebilecek kısa dönem dengesizliğini gösteren katsayının $(\eta)$ negatif işaretli ve istatistiksel olarak anlamlı olması beklenmektedir. Bu bağlamda (4) numaralı denklemin tahmininden elde edilen sonuçlar Tablo 4'de sunulmuştur.

Tablo 4. ARDL Modeli Hata Düzeltme Katsayısı Tahminleri

\begin{tabular}{|c|c|c|c|c|}
\hline Değişken & Katsayı & Standart Hata & t-istatistiği & Prop. \\
\hline$\Delta \mathrm{KB} 1$ & 0.267 & 0.130 & 2.050 & $0.050 * *$ \\
\hline$\Delta \mathrm{KB} 1(-1)$ & -0.188 & 0.102 & -1.849 & $0.075 * *$ \\
\hline$\Delta \mathrm{KB} 1(-2)$ & -0.192 & 0.073 & -2.621 & $0.014 * *$ \\
\hline Dummy & 1.099 & 0.440 & 2.494 & $0.019 * *$ \\
\hline $\mathrm{ecm}_{\mathrm{t}-1}$ & -0.381 & 0.107 & -3.547 & $0.001 * * *$ \\
\hline \multicolumn{5}{|c|}{$\mathrm{ecm}_{\mathrm{t}-1}=F D D-(0.569 * K B 1+2.887 * D u m m y-2.229)$} \\
\hline $\mathbf{R}^{2}$ & & 0.82 & Düzeltilmiş $\mathbf{R}^{2}$ & 0.78 \\
\hline AIC & & 2.989 & F-İstatistiği & $21.664[0,000]$ \\
\hline DW-istatistiği & & 2.040 & $\chi_{B G}^{2}$ & $0.527[0.415]$ \\
\hline Jarque-Bera & & $0.091[0.955]$ & $\chi_{B P G}^{2}$ & $1.999[0.286]$ \\
\hline
\end{tabular}

Not: $*, * *, * * *$ sirasıly $\% 10, \% 5$ ve $\% 1$ düzeyinde istatistiksel olarak anlamlılık düzeyini ifade etmektedir. AIC, Akaike Bilgi Kriteri. DW-istatistiği, Durbin-Watson istatistiği. $\chi_{B G}^{2}$, BreuschGodfrey LM sıra korelasyon testi. $\chi_{B P G}^{2}$, Breusch-Pagan-Godfrey değişen varyans testi.

Hata düzeltme terimi $\left(\mathrm{ecm}_{t-1}\right)$ negatif işaretli ve istatistiksel olarak anlamlı bulunmuştur. Tahmin edilen model $\% 82$ oranında kabul edilebilir bir açıklama gücüne sahiptir. Modele ait parametrelerin tümünün birlikte anlamlılığını kontrol eden $\mathrm{F}$ 
SONGUR, ELMAS SARAÇ | Fiscal Theory of the Price Level and Ricardian Fiscal Policy...

istatistiği \%1 düzeyinde istatistiksel olarak anlamlı bulunmuştur. ARDL modelinin normallik dağılımı Jarque-Bera testi, değişen varyans sorunu Breusch-Pagan-Godfrey Heteroskedastisity testi ve otokorelasyon sorunu Breusch-Godfrey Sira Korelasyon LM testi kullanılarak tespit edilmeye çalışılmıştır. Jarque-Bera testine göre hata terimlerinin normal dağıldığ dağılımına uymaktadır. Breusch-Pagan-Godfrey Heteroskedastisite Testi’ne göre değişen varyans sorunu olmadığını yani kalıntıların homoskedastik olduğunu ifade eden yokluk hipotezi reddedilememektedir. Yani kalıntıların istatistiksel olarak \%5 anlamlılık düzeyinde homoskedastik olduğu sonucuna varılmıştır. için modelde değişen varyans sorunu yoktur. Breusch-Godfrey otokorelasyon testine göre kalıntıların otokorelasyona sahip olmadığını ifade eden yokluk hipotezi reddedilememiştir.

Son olarak, modelin tahmininden elde edilen katsayıların kararlılığı CUSUM (kümülatif toplam) ve CUSUMSQ (kümülatif karelerin toplamı) testleri ile sınanmıştır. Şekil 2'de CUSUM test grafiği elde edilen parametrelerin \%5 anlamlılık düzeyinde kararlı olduğunu göstermektedir. Şekil 3'de CUSUMSQ testi için sunulan grafik CUSUM testini destekleyerek parametrelerin \%5 anlamlılık düzeyinde kararlı olduğuna işaret etmektedir.

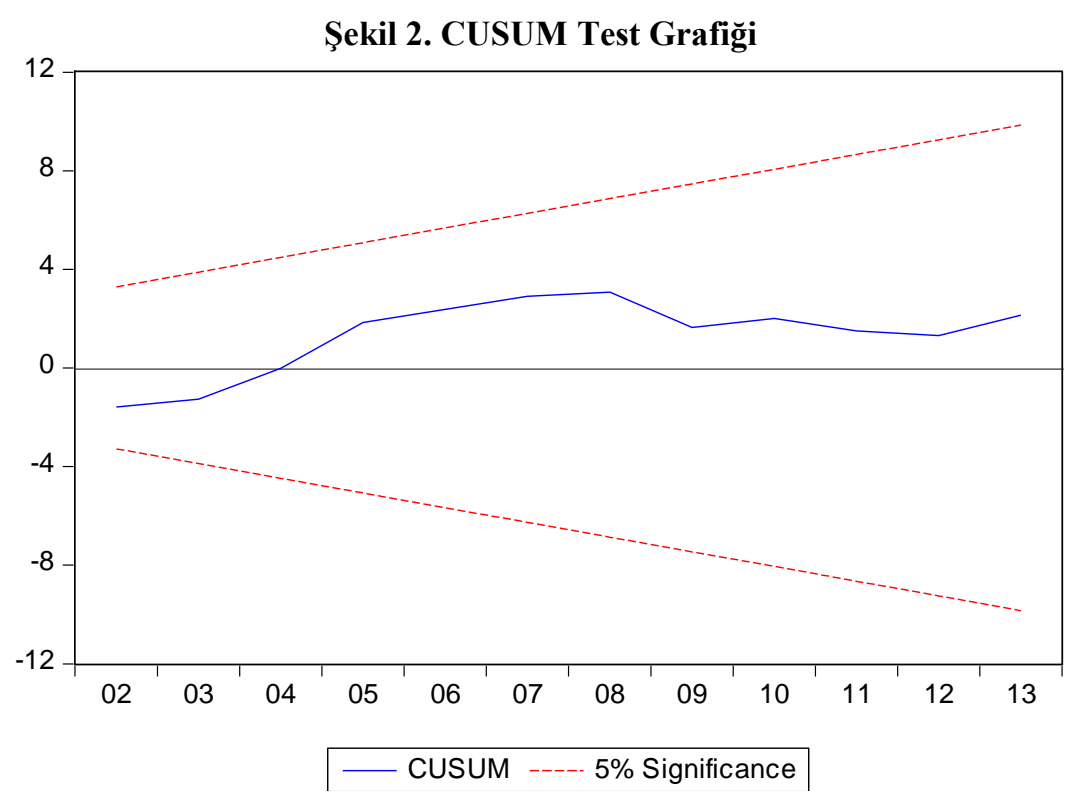

Hacettepe University Journal of Economics and Administrative Sciences 


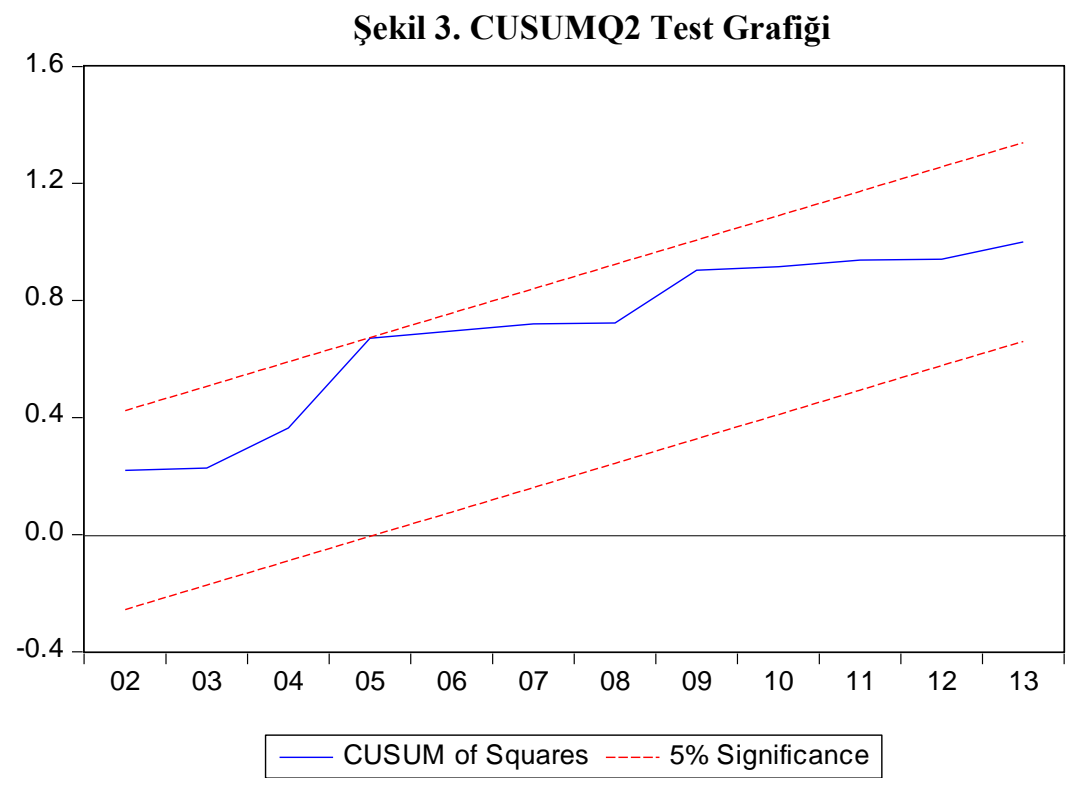

Elde edilen bulgulara göre uzun dönem kamu borcu/GSYH değişkenine ilişkin katsayının pozitif ( 0.569$)$ ve $\% 5$ düzeyinde istatistiksel olarak anlamlı çıkması ve 2001 yllında gerçekleşen iktisadi politika rejiminin değiştiğini ifade eden kukla değişkenin pozitif ve anlamlı çıkması bağlamında özellikle 2001 yılından sonra Ricardocu Maliye Politikası'nın geçerli olduğunu söyleyebiliriz.

Bununla birlikte, elde ettiğimiz sonuçlar, hem FDD değişkeninin durağan olmaması hem de kısa dönem katsayılarında KB1 değişsenine ait birinci ve ikinci dönem gecikmelerin negatif olarak tahmin edilmiş olması Ricardocu olmayan maliye politikası yönünde de bulgular göstermektedir.

\section{SONUÇ}

Para ve maliye politikalarının fiyat istikrarının sağlanması ve istikrarın korunması konusunda birbirini etkileyip etkilemedikleri literatürde halen önemini koruyan bir tartışmadır. Geleneksel makro iktisat teorileri fiyat istikrarının parasal bir olgu olduğunu vurgulamakta ve maliye politikası ne olursa olsun bağımsız bir merkez bankasının uygulayacağı para politikasının yeterli olacağını savunmaktadır. Ricardocu Maliye Politikası olarak anılan bu görüş̧e göre maliye politikaları ekonomide herhangi bir servet etkisi ve dolayısıyla da genel fiyat istikrarını bozucu bir etki yaratmayacaktır. Diğer taraftan, maliye politikasının gerekli disiplinden yoksun olduğu durumda, merkez bankasının fiyat istikrarını sağlamak amacıyla etkili politikalar yürütemeyeceğini savunan iktisatçıların ortaya attığı görüş̧e Fiyat Düzeyinin Mali Teorisi denilmektedir. 
SONGUR, ELMAS SARAÇ | Fiscal Theory of the Price Level and Ricardian Fiscal Policy...

$\mathrm{Bu}$ görüşe göre, genel fiyat düzeyinin bütçe kısıtının bugünkü değeri tarafından belirleneceğini savunmaktadır.

Çalışmada Türkiye için fiyat düzeyinin belirlenmesinde maliye politikalarının etkili olup olmadığ 1975-2014 dönemine ait veriler kullanılarak ARDL Sınır Testi yaklaşımı ile araştırılmıştır. Türkiye 2001 yılına kadar para politikasında enflasyon hedefine odaklanamamıştır. Bu durumun temel nedeni, kamu dengesinde yaşanan dengesizliklerin büyük çoğunlukla para politikası araçları kullanılarak giderilmesidir. $\mathrm{Bu}$ nedenle fiyat istikrarında ciddi bozulmalar meydana gelmiştir. 2001 yılında yaşanan kriz ve devamında uygulamaya konulan Güçlü Ekonomiye Geçiş Programı ile para politikası fiyat istikrarına odaklanırken, maliye politikası ise faiz dışı bütçe fazlasına yönelmiştir. Dolayısıyla her iki politikanın birbirinden bağımsız hedeflere yönelmesi, iktisadi politika rejiminin değiştiğini göstermektedir.

2001 yılında yaşanan kriz ve devamında gerçekleşen iktisadi politika rejimindeki değişiklik nedeniyle 2001 yılında kırılma olduğu düşünülerek modele bir kukla değişken eklenmiştir. Elde edilen bulgulara göre faiz dışı bütçe fazlası ile bir dönem gecikmesi alınmış kamu borcu arasında uzun dönemli bir eş bütünleşme ilişkisi olduğu tespit edilmiştir. ARDL modelinden elde edilen uzun dönem katsayılara baktığımızda, kamu borcu değişkenine ait katsayı pozitif ve istatistiksel olarak anlamlı bulunmuştur. 2001 yilından sonra gerçekleşen iktisadi politika değişikliğini ifade etmek için konulan kukla değişkenin pozitif ve istatistiksel olarak anlamlı çıkması nedeniyle Türkiye'de özellikle 2001 yılından sonra Ricardocu Maliye Politikası'nın uygulandığı ifade edilebilir. Bununla birlikte -özellikle kısa dönemde- Ricardocu olmayan maliye politikasına ilişkin bulgular elde edilmiştir.

2001 yılından sonra Türkiye'de para politikasının fiyat istikrarını sağlamak amacı ve maliye politikasının da Maastricht Kriterleri’ne uygun olarak bütçe açıklarını ve kamu borcunu dikkate alan politikalar izlemesi çalışmadan elde edilen bulgular ile paralellik göstermektedir.

\section{NOTLAR}

${ }^{1}$ Zamanlararası Bütçe Kısıtı, mevcut kamu borç stokunun gelecek dönemdeki faiz dışı fazlaların şimdiki değerine eşit olmasıdır.

2 1977-79 dönemi para arzındaki yıllık ortalama artış oranı \%41.9 olarak gerçekleşmiştir (Şahin, 2012: 172).

${ }^{3}$ GSYH 1998 yılı fiyatları ile reel hale getirilmiştir.

${ }^{4}$ Mali sürdürülebilirlik literatüründe, FDD'nin birinci farkı alındığında durağan hale gelmesi durumunda Ricardocu olmayan maliye politikalarının geçerli olduğunu belirten çalışmalarda mevcuttur (Ersin, 2011). 


\section{REFERANSLAR}

Afonso, A. (2002), Disturbing the Fiscal Theory of the Price Level: Can it Fit the EU-15?. Working Paper. https://www.econpapers.repec.org/cpd/2002/5_Afonso.pdf, E.T.: 10.11.2014.

Arıcan, E. (2005), "Ricardocu Denklik Teoremi ve Teorilerde Kamu Açıklarına İlişkin Yaklaşımlar: Türkiye Ekonomisine İlişkin Bir Uygulama”, Marmara Üniversitesi I.I. B.F. Dergisi, 20(1), 77-94.

Barro, R.J. (1974), “Are Government Bonds Net Wealth?”, Journal of Political Economy, 82(6), $1095-1117$.

Bildirici, M., Ersin, Ö. Ö. (2005), "Fiscal Theory of Price Level and Economic Crises: The Case of Turkey", Journal of Economic and Social Research, 7(2), 81-114.

Buchanan J.M., (1976), "Barro on the Ricardian Equivalence Theorem", Journal of Political Economy, 84(2), 337-342.

Cochrane, J.H. (2001), "Long-term Debt and Optimal Policy in the Fiscal Theory of the Price Level”, Econometrica, 69(1), 69-116.

Creel, J., Kamber, G. (2004), "Debt, Deficits and Inflation on the Road to the EU: The Case of Turkey”, Revue de I'OFCE Presses de Sciences-Po, 91(5), 157-174.

Dickey, D.A., Fuller, W.A. (1981), "Likelihood Ratio Statistics for Autoregressive Time Series with a Unit Root", Econometrica, 49, 1057-1072.

Elmas, F., Songur, M. (2016), "Ricardocu Mali Rejim ve Fiyat Düzeyinin Mali Teorisi: Avrupa Para Sistemi Örneği”, Ekonomik Yaklaşım, 27(99), 203-236.

Ersin, Ö.Ö. (2011), “Türkiye'de Mali Sürdürülebilirliğin Doğrusal Olmayan Bir Analizi: MLSTAR Çoklu Lojistik Yumuşak Geçişli Otoregresif Modeli”, Ege Akademik Bakış Dergisi, 11(Özel Say1), 41-58.

Güney, P.Ö. (2007), "Yeni Fiyat Belirleme Teorisi ve Türkiye Örneği”, Yayınlanmamış Doktora Tezi, Ankara: Hacettepe Üniversitesi Sosyal Bilimler Enstitüsü İktisat Ana Bilim Dalı.

Güney, P.Ö. (2009), "Yeni Fiyat Belirleme Teorisi: Bir Literatür Taraması", Hacettepe Üniversitesi Íktisadi ve İdari Bilimler Fakültesi Dergisi, 27(1), 25-44.

Leeper, E. (1991), "Equilibria under 'Active' and 'Passive' Monetary and Fiscal Policies", Journal of Monetary Economics, 27, 129-147.

Metin, K. (1995), “An Integrated Analysis of Turkish Inflation”, Oxford Bulletin of Economics and Statistics, 57(4), 513-531.

Metin, K. (1998), "The Relationship Between Inflation and the Budget Deficit in Turkey", Journal of Business \& Economic Statistics, 16(4), 412-422.

Narayan, P.K. (2004). Reformulating Critical Values for the Bounds F-statistics Approach to Cointegration: An Application to the Tourism Demand Model for Fiji, Discussion Paper, 02/04.

Oktayer, A. (2010), “Türkiye'de Bütçe Açı̆̆ı, Para Arzı ve Enflasyon İlişkisi”, Maliye Dergisi, $158,431-447$.

Özaktaş, F.D. (2008), "Fiyat Düzeyinin Belirlenmesinde Yeni Yaklaşımlar ve Türkiye Deneyimi”, Akademik Incelemeler, 3(1), 157-174. 
SONGUR, ELMAS SARAÇ | Fiscal Theory of the Price Level and Ricardian Fiscal Policy...

Perron, P. (1989), "The Great Crash, the Oil Price Shock and the Unit Root Hypothesis", Econometrica, 57(6), 1361-1401.

Pesaran, M.H., Y. Shin, R.J. Smith (2001), "Bound Testing Approaches to the Analysis of Long Run Relationships”, Journal of Applied Econometrics, 16, 289-326.

Phillips, P.C.B., P. Perron (1988), "Testing for a Unit Root in Time Series Regression", Biometrica, 75(2), 335-346.

Saçkan, O. (2006), Genel Fiyat Düzeyinin Belirlenmesinde Para Ve Maliye Politikası Dominant Rejimler: Türkiye Örneği, 1988-2005, Uzmanlık Yeterlilik Tezi, Ankara: Türkiye Cumhuriyet Merkez Bankası Emisyon Genel Müdürlüğü.

Sims, A.C. (1993), A Simple Model for Study of the Determination of the Price Level and the Interaction of Monetary and Fiscal Policy, Working Paper. http://sims.princeton.edu/yftp/MnF/M\&fpape4.pdf, E. T.: 12.11.2014.

Sims, A.C. (1997), "Fiscal Foundations of Price Stability on Open Economies", NBER Working Paper 5684. http://papers.ssrn.com/sol3/papers.cfm?abstract_id=75357, E.T.: 12.11.2014.

Şahin, H. (2012), Türkiye Ekonomisi, (12. Baskı), Bursa, Ezgi Kitapevi Yayınları.

Temiz, D. (2008), Fiyat Düzeyinin Mali Teorisi (FTPL): Türkiye'nin 1980-2005 Dönemi İçin Model Uygulamaları, Yayınlanmamış Doktora Tezi, Ankara: Ankara Üniversitesi Sosyal Bilimler Enstitüsü İktisat Ana Bilim Dalı.

Uygur, E. (2001), "Enflasyon Para ve Mali Baskı: İktisat Politikasında Geri Kalmışlık”, İktisat İşletme ve Finans, 189, 7-22.

Uysal, Ö., G.G. Pehlivan (2013), “Avrupa Parasal Birliği Bağlamında Ricardocu Mali Rejim”, Süleyman Demirel Üniversitesi İktisadi ve İdari Bilimler Fakültesi Dergisi, 18(1), 271282.

Woodford, M. (1994), "Monetary Policy and Price Level Determinacy in a Cash-in-Advance Economy”, Economic Theory, 4(3), 345-380.

Woodford, M. (1995), Price Level Determinancy Without Control of a Monetary Aggregate. NBER Working Paper 5204. http://www.nber.org/papers/w5204, E. T.: 12.11.2014.

Woodford, M. (2001), Fiscal Requirements for Price Stability, NBER Working Paper 8072, http://www.nber.org/papers/w8072, E.T.: 12.11.2014. 